\title{
X-RAY STRUCTURE AND SPECTROSCOPIC PROPERTIES OF PLATINUM(II) COMPLEXES OF 1,1'-BIISOQUINOLINE
}

\author{
LUK-KI CHENG, KẠP-SUN YEUNG and CHI-MING CHE $\uparrow$ \\ Department of Chemistry, The University of Hong Kong, Pokfulam Road, Hong Kong
}

and

\section{MING-CHU CHENG and YU WANG}

Department of Chemistry, National Taiwan University, Taipei, Taiwan, R.O.C.

(Received 11 December 1992 ; accepted 8 January 1993)

\begin{abstract}
Three platinum(II) complexes of biq (biq $=1,1^{\prime}$-biisoquinoline), $\left[\mathrm{Pt}(\mathrm{biq}) \mathrm{Cl}_{2}\right]$, $\left[\mathrm{Pt}(\right.$ biq $\left.)(\mathrm{py})_{3}\right]\left(\mathrm{ClO}_{4}\right)_{2}$ (py = pyridine) and $\left[\mathrm{Pt}(\right.$ biq $\left.)(\text { dapy })_{3}\right]\left(\mathrm{ClO}_{4}\right)_{2} \quad[$ dapy $=4$ - $($ dimethylamino)pyridine] were prepared. Using ${ }^{1} \mathrm{H}$ NMR spectroscopy and $\mathrm{X}$-ray crystallography, biq in the former complex was found to be bidentate and in the two latter complexes monodentate. Dihedral angles between the two isoquinoline rings were determined to be $35.18^{\circ}$ and $41.12^{\circ}$ in $\left[\mathrm{Pt}(\right.$ biq $\left.) \mathrm{Cl}_{2}\right]$ and $77.61^{\circ}$ in $\left[\mathrm{Pt}(\mathrm{biq})(\mathrm{dapy})_{3}\right]\left(\mathrm{ClO}_{4}\right)_{2}$. The crystal structure of $\left[\mathrm{Pt}(\mathrm{biq}) \mathrm{Cl}_{2}\right]$ is the first example of $\eta^{2}-\mu_{1}$ biq complexes with a fivemembered chelating ring. Weak intramolecular $\pi-\pi$ stacking occurs in the solid phase of $\left[\mathrm{Pt}(\right.$ biq $\left.)(\text { dapy })_{3}\right]\left(\mathrm{ClO}_{4}\right)_{2}$.
\end{abstract}

Ligands incorporating a 1,1'-binaphthyl unit have been receiving current interest because of their application in catalytic asymmetric reactions. ${ }^{1}$ In our search for new metal catalysts for asymmetric organic oxidation the ligand 1,1'-biisoquinoline (biq), which possesses the combined structural features of 2,2'-bipyridine (bpy) and 2,2'-bis(diphenylphosphino)-1,1'-binaphthyl, has attracted our interest. Dai et al. first reported the X-ray crystal structure of a chiral palladium complex of biq, in which the ligand acts as a bridging ligand. ${ }^{2}$ Here we describe three mononuclear platinum(II)biq complexes, $\left[\mathrm{Pt}(\right.$ biq $\left.) \mathrm{Cl}_{2}\right],\left[\mathrm{Pt}(\right.$ biq $\left.)(\mathrm{py})_{3}\right]\left(\mathrm{ClO}_{4}\right)_{2}$ and $\left[\mathrm{Pt}(\right.$ biq $\left.)(\text { dapy })_{3}\right]\left(\mathrm{ClO}_{4}\right)_{2}$, with the crystal structures of $\left[\mathrm{Pt}(\right.$ biq $\left.) \mathrm{Cl}_{2}\right]$ and $\left[\mathrm{Pt}(\right.$ biq $\left.)(\text { dapy })_{3}\right]\left(\mathrm{ClO}_{4}\right)_{2}$ determined.

\section{EXPERIMENTAL}

\section{Physical measurements}

UV-vis absorption spectra were recorded with a Shimadzu UV-240 spectrophotometer or a Milton

$\uparrow$ Author to whom correspondence should be addressed.
Roy Spectronic 3000 Array spectrophotometer in acetonitrile. NMR spectra were run on a Jeol GSX 270 spectrometer. Chemical shifts $(\delta / \mathrm{ppm})$ were reported relative to tetramethylsilane (TMS).

\section{$X$-ray structure determination}

Crystals of $\left[\mathrm{Pt}(\mathrm{biq}) \mathrm{Cl}_{2}\right]$ were obtained by the addition of diethyl ether to a dimethyl formamide solution of $\left[\mathrm{Pt}(\mathrm{biq}) \mathrm{Cl}_{2}\right]$. Yellow crystals of [Pt(dapy) (dapy) $\left.{ }_{3}\right]\left(\mathrm{ClO}_{4}\right)_{2}$ were obtained by diffusion of diethyl ether into acetonitrile solution. X-ray diffraction data were collected on an Enraf-Nonius CAD4 diffractometer with graphite-monochromated Mo$K_{\alpha}$ radiation $(\lambda=0.71069 \AA)$ using the $\omega / 2 \theta$ scan mode. Details of crystal parameters, data collection and structure refinement are given in Table 1. Cell dimensions were obtained from 24 reflections with $2 \theta$ in the ranges $18.90-23.60^{\circ}$ and 18.84 $29.16^{\circ}$ for $\left[\mathrm{Pt}(\right.$ biq $\left.) \mathrm{Cl}_{2}\right]$ and $\left[\mathrm{Pt}(\right.$ biq $\left.)(\text { dapy })_{3}\right]\left(\mathrm{ClO}_{4}\right)_{2}$, respectively. All reflections were corrected for Lorentz, polarization and absorption effects. All data reduction and structure refinement were performed using the NRCC-SDP-VAX packages. ${ }^{3}$ The structure was solved by the Patterson method 
Table 1. Crystallographic data for $\left[\mathrm{Pt}(\mathrm{biq}) \mathrm{Cl}_{2}\right]$ and $\left[\mathrm{Pt}(\mathrm{biq})(\mathrm{dapy})_{3}\right]\left(\mathrm{ClO}_{4}\right)_{2}$

\begin{tabular}{|c|c|c|}
\hline & {$\left[\mathrm{Pt}(\mathrm{biq}) \mathrm{Cl}_{2}\right]$} & {$\left[\mathrm{Pt}\right.$ (biq) $\left.(\text { dapy })_{3}\right]\left(\mathrm{ClO}_{4}\right)_{2} \cdot 0.5\left(\mathrm{C}_{2} \mathrm{H}_{5}\right)_{2} \mathrm{O}$} \\
\hline \multicolumn{3}{|l|}{ Crystal data } \\
\hline Empirical formula & $\mathrm{C}_{18} \mathrm{H}_{12} \mathrm{~N}_{2} \mathrm{Cl}_{2} \mathrm{Pt}$ & $\mathrm{C}_{41} \mathrm{H}_{47} \mathrm{~N}_{8} \mathrm{O}_{8.5} \mathrm{Cl}_{2} \mathrm{Pt}$ \\
\hline Formula weight & 522.29 & 1053.86 \\
\hline System & Monoclinic & Triclinic \\
\hline Space group & $P 2_{1} / c$ & $P \overline{1}$ \\
\hline$a(\AA)$ & $14.644(4)$ & $11.553(5)$ \\
\hline$b(\AA)$ & $19.973(4)$ & $14.208(2)$ \\
\hline$c(\AA)$ & $11.127(2)$ & $14.378(5)$ \\
\hline $\begin{array}{l}\alpha\left({ }^{\circ}\right) \\
\beta\left(r^{\circ}\right)\end{array}$ & & $\begin{array}{l}85.96(2) \\
97.70(3)\end{array}$ \\
\hline $\begin{array}{l}\beta\left(^{\circ}\right) \\
\gamma\left({ }^{\circ}\right)\end{array}$ & $101.93(2)$ & $\begin{array}{l}97.70(3) \\
100.07(3)\end{array}$ \\
\hline$V\left(\AA^{3}\right)$ & $3184(1)$ & $2300(1)$ \\
\hline$Z$ & 8 & 2 \\
\hline$\rho_{\text {calc. }}\left(\mathrm{g} \mathrm{cm}^{-3}\right)$ & 2.179 & 1.52 \\
\hline$\mu\left(\mathrm{cm}^{-1}\right)$ & 92.4 & 32.5 \\
\hline$F(000)$ & 1968 & 1058 \\
\hline Temperature (K) & 297 & 297 \\
\hline \multicolumn{3}{|c|}{ Data collection, reduction, solution and refinement } \\
\hline Scan range & $0.8+0.35 \tan \theta$ & $0.9+0.35 \tan \theta$ \\
\hline Scan speed $\left({ }^{\circ} \min ^{-1}\right)$ & $2.06-8.24$ & $2.35-8.24$ \\
\hline Crystal dimensions (mm) & $0.20 \times 0.20 \times 0.30$ & $0.50 \times 0.50 \times 0.40$ \\
\hline \multirow{3}{*}{ Range $h, k, l$} & $-17-17$ & $-13-13$ \\
\hline & $0-23$ & $0-16$ \\
\hline & $0-13$ & $-16-17$ \\
\hline Total no. of reflections & 5594 & 8078 \\
\hline \multicolumn{3}{|l|}{ No. of observed } \\
\hline reflections $(I>2 \sigma(I))$ & 3271 & 6639 \\
\hline \multicolumn{3}{|l|}{ No. of atoms and } \\
\hline parameters refined & 70,415 & 106,504 \\
\hline \multicolumn{3}{|l|}{ Residual electron } \\
\hline$R^{a}$ & 0.040 & 0.053 \\
\hline$R_{\mathrm{w}}{ }^{b}$ & 0.032 & 0.050 \\
\hline$S^{c}$ & 1.77 & 4.45 \\
\hline
\end{tabular}

${ }^{a} R_{\mathrm{f}}=\Sigma\left(\left|F_{\mathrm{o}}\right|-\mid F_{\mathrm{c}}\right) / \Sigma\left|F_{\mathrm{o}}\right|$

${ }^{b} R_{\mathrm{w}}=\left[\Sigma\left(\mathrm{w}|| F_{\mathrm{o}}|-| F_{\mathrm{c}} \|^{2}\right) / \Sigma \mathrm{w}\left|F_{\mathrm{o}}\right|^{2}\right]^{1 / 2}$.

${ }^{c} S=\left[\Sigma\left(\left.w|| F_{\mathrm{o}}|-| F_{\mathrm{c}}\right|^{2}\right) /(n-p)\right]^{1 / 2} ; n$ is the number of observed reflections, $p$ is the number of parameters used.

and refined by least-squares. Selected bond distances and angles for $\left[\mathrm{Pt}(\mathrm{biq}) \mathrm{Cl}_{2}\right]$ and $[\mathrm{Pt}($ biq) (dapy) $\left.)_{3}\right]\left(\mathrm{ClO}_{4}\right)_{2}$ are given in Tables 2 and 3, respectively.

\section{Materials}

Potassium tetrachloroplatinate(II) $\quad\left(\mathrm{K}_{2} \mathrm{PtCl}_{4}\right)$ and isocarbostyril were purchased from Aldrich Chemical Company, Inc. Nickel chloride (GPR) $\left(\mathrm{NiCl}_{2} \cdot 6 \mathrm{H}_{2} \mathrm{O}\right)$ and zinc powder (LR) were purchased from $\mathrm{BDH}$. 4-(Dimethylamino)pyridine (dapy) and triphenylphosphine $\left(\mathrm{PPh}_{3}\right)$ were pur- chased from Merck. All chemicals and solvents were used without further purification.

\section{Syntheses}

The ligand biq was prepared by homo-coupling of 1-bromoisoquinoline catalysed by $\mathrm{NiCl}_{2}-$ $\mathrm{PPh}_{3} \mathrm{Zn}$ in $20 \%$ yield. ${ }^{4} 1$-Bromoisoquinoline was prepared by bromination of isocarbostyril with phosphorus tribromide $\left(\mathrm{PBr}_{3}\right)$.

$\left[\mathrm{Pt}(\mathrm{biq}) \mathrm{Cl}_{2}\right]$ was prepared in a similar manner to $\left[\mathrm{Pt}\right.$ (substituted 2,2'-bipyridine) $\left.\mathrm{Cl}_{2}\right] .{ }^{5}$ In a typical reaction a mixture of $\mathrm{K}_{2} \mathrm{PtCl}_{4}(0.10 \mathrm{~g})$ and biq $(0.07$ 
Table 2. Selected bond distances $(\AA)$ and angles $\left({ }^{\circ}\right)$ for $\left[\operatorname{Pt}(\right.$ biq $\left.) \mathrm{Cl}_{2}\right]$

\begin{tabular}{llll}
\hline \multicolumn{3}{l}{ Type I } & \multicolumn{1}{l}{ Type II } \\
\hline $\mathrm{Pt}(1)-\mathrm{Cl}(1)$ & $2.295(4)$ & $\mathrm{Pt}(2)-\mathrm{Cl}(3)$ & $2.293(4)$ \\
$\mathrm{Pt}(1)-\mathrm{Cl}(2)$ & $2.278(4)$ & $\mathrm{Pt}(2)-\mathrm{Cl}(4)$ & $2.276(4)$ \\
$\mathrm{Pt}(1)-\mathrm{N}(1)$ & $1.99(1)$ & $\mathrm{Pt}(2)-\mathrm{N}(21)$ & $1.99(1)$ \\
$\mathrm{Pt}(1)-\mathrm{N}(11)$ & $2.00(1)$ & $\mathrm{Pt}(2)-\mathrm{N}(31)$ & $2.00(1)$ \\
$\mathrm{Cl}(1)-\mathrm{Pt}(1)-\mathrm{Cl}(2)$ & $88.7(2)$ & $\mathrm{Cl}(3)-\mathrm{Pt}(2)-\mathrm{Cl}(4)$ & $89.8(2)$ \\
$\mathrm{Cl}(1)-\mathrm{Pt}(1)-\mathrm{N}(1)$ & $95.5(3)$ & $\mathrm{Cl}(3)-\mathrm{Pt}(2)-\mathrm{N}(21)$ & $95.4(3)$ \\
$\mathrm{Cl}(2)-\mathrm{Pt}(1)-\mathrm{N}(11)$ & $96.1(3)$ & $\mathrm{Cl}(4)-\mathrm{Pt}(2)-\mathrm{N}(31)$ & $94.7(4)$ \\
$\mathrm{N}(1)-\mathrm{Pt}(1)-\mathrm{N}(11)$ & $79.7(4)$ & $\mathrm{N}(21)-\mathrm{Pt}(2)-\mathrm{N}(31)$ & $80.3(5)$ \\
$\mathrm{C}(2)-\mathrm{N}(1)-\mathrm{C}(10)$ & $117(1)$ & $\mathrm{C}(22)-\mathrm{N}(21)-\mathrm{C}(30)$ & $119(1)$ \\
$\mathrm{C}(12)-\mathrm{N}(11)-\mathrm{C}(20)$ & $118(1)$ & $\mathrm{C}(32)-\mathrm{N}(31)-\mathrm{C}(40)$ & $120(1)$ \\
\hline
\end{tabular}

g) in water $\left(20 \mathrm{~cm}^{3}\right)$ was heated to boiling for $\frac{1}{2}-1$ $h$. The solid precipitate was filtered and washed with dilute hydrochloric acid, water and finally ethanol. The orange solid product yielded $88 \%$. UV-vis spectral data in acetonitrile $\left[\lambda / \mathrm{nm}\left(\varepsilon / \times 10^{4} \mathrm{~mol}^{-1}\right.\right.$ $\left.\mathrm{dm}^{3} \mathrm{~cm}^{-1}\right)$ ] : 245 (3.10), 302 (1.20), 385 (1.06), 404 (1.19), $446(0.50)$.

The complexes $\left[\mathrm{Pt}(\mathrm{biq})(\mathrm{py})_{3}\right]\left(\mathrm{ClO}_{4}\right)_{2}$ and $[\mathrm{Pt}(\mathrm{biq})$ (dapy) $\left.{ }_{3}\right]\left(\mathrm{ClO}_{4}\right)_{2}$ were prepared in a similar manner to that for $\left[\mathrm{Pt}(\mathrm{bpy})(\mathrm{py})_{2}\right]^{2+}$ by Bielli et al. ${ }^{5}$ In a typical reaction a mixture of $\left[\mathrm{Pt}(\mathrm{biq}) \mathrm{Cl}_{2}\right](0.13 \mathrm{~g})$ and pyridines (py, dapy; $1 \mathrm{~cm}^{3}$ ) in ethanol was warmed at $c a 50^{\circ} \mathrm{C}$ for $c a 10$ min until the orange suspension turned to a clear pale-yellow solution. The reaction mixture was filtered and excess $\mathrm{LiClO}_{4}$ was added to the filtrate to give a pale yellow solid, which was filtered and washed with ethanol and diethyl ether. Anal. for [ $\left.\mathrm{Pt}(\mathrm{biq})(\mathrm{py})_{3}\right]\left(\mathrm{ClO}_{4}\right)_{2}\left(\mathrm{PtC}_{33}\right.$ $\mathrm{H}_{27} \mathrm{~N}_{5} \mathrm{O}_{8} \mathrm{Cl}_{2}$ ): Found: $\mathrm{C}, 44.0 ; \mathrm{H}, 2.7 ; \mathrm{N}, 7.8$. Calc. : C, $44.7 ; \mathrm{H}, 3.1 ; \mathrm{N}, 7.9 \%$. UV-vis spectral data in acetonitrile $\left[\lambda / \mathrm{nm}\left(\varepsilon / \times 10^{4} \mathrm{~mol}^{-1} \mathrm{dm}^{3}\right.\right.$ $\left.\left.\mathrm{cm}^{-1}\right)\right]: \quad\left[\mathrm{Pt}(\mathrm{biq})(\mathrm{py})_{3}\right]\left(\mathrm{ClO}_{4}\right)_{2}: 251 \quad$ (3.02), 325 (2.10), 339 (shoulder); [ $\mathrm{Pt}($ biq)(dapy) $]$ ] $\left(\mathrm{ClO}_{4}\right)_{2}: 288$ (0.47), 325 (shoulder).

\section{RESULTS AND DISCUSSION}

The UV-vis spectral data of $\left[\mathrm{Pt}(\mathrm{biq})(\mathrm{py})_{3}\right]\left(\mathrm{ClO}_{4}\right)_{2}$ and $\left[\mathrm{Pt}(\right.$ biq $\left.)(\text { dapy })_{3}\right]\left(\mathrm{ClO}_{4}\right)_{2}$ show two allowed tran- sition bands between 200 and $400 \mathrm{~nm}$, which are assigned to intraligand $\pi-\pi^{*}$ transitions. The UVvis absorption spectrum of $\left[\mathrm{Pt}(\mathrm{biq}) \mathrm{Cl}_{2}\right]$ is similar to that of $\left[\mathrm{Pt}(\mathrm{LL}) \mathrm{Cl}_{2}\right]$ reported by Gidney et al. ${ }^{6}$

Perspective drawings of the molecule and unit cell of $\left[\mathrm{Pt}(\mathrm{biq}) \mathrm{Cl}_{2}\right]$ are given in Figs 1 and 2, respectively. In [ $\mathrm{Pt}($ biq $) \mathrm{Cl}_{2}$ ] two kinds of configuration were found and they are principally different in the dihedral angles between the two isoquinoline planes. The one with smaller dihedral angle is designated type I $\left(35.18^{\circ}\right)$ and another one type II $\left(41.12^{\circ}\right)$. In both types the platinum atom is in a slightly distorted square-planar coordination geometry. The two isoquinoline moieties are bent away from the coordination plane in opposite directions as a result of mutual repulsion between protons 8 and $8^{\prime}$ on the biq moiety. Similar to $\left[\mathrm{Pt}(\mathrm{bpy}) \mathrm{Cl}_{2}\right],{ }^{5,7}$ dimorphism occurs in [ $\left.\mathrm{Pt}(\mathrm{biq}) \mathrm{Cl}_{2}\right]$. The freshly prepared $\left[\mathrm{Pt}(\right.$ biq $\left.) \mathrm{Cl}_{2}\right]$ was orange in colour, but after recrystallization from dimethyl formamide dark brown crystals were obtained. An orange solid was precipitated when recrystallization was attempted in a water-acetone mixture. The difference in crystal colour is believed to be due to a change in the degree of hydration. Although $\left[\mathrm{Pt}(\right.$ biq $\left.) \mathrm{Cl}_{2}\right]$ is similar to $\left[\mathrm{Pt}\right.$ (bpy) $\left.\mathrm{Cl}_{2}\right]$ in exhibiting dimorphism, no superimposition of molecules is found in the crystal structure of $\left[\mathrm{Pt}(\mathrm{biq}) \mathrm{Cl}_{2}\right]$, as shown in $\left[\mathrm{Pt}(\mathrm{bpy}) \mathrm{Cl}_{2}\right]{ }^{7}$ The intermolecular $\mathrm{Pt}-\mathrm{Pt}$

Table 3. Selected bond distances $(\AA)$ and angles $\left({ }^{\circ}\right)$ for $\left[\mathrm{Pt}(\mathrm{biq})(\text { dapy })_{3}\right]\left(\mathrm{ClO}_{4}\right)_{2}$

\begin{tabular}{lrlrr}
\hline $\mathrm{Pt}-\mathrm{N}(1)$ & $2.038(7)$ & $\mathrm{Pt}-\mathrm{N}(31)$ & \multicolumn{1}{c}{$1.997(7)$} \\
$\mathrm{Pt}-\mathrm{N}(21)$ & $2.022(8)$ & $\mathrm{Pt}-\mathrm{N}(41)$ & $2.021(8)$ \\
$\mathrm{N}(1)-\mathrm{Pt}-\mathrm{N}(21)$ & $91.9(3)$ & & $\mathrm{N}(31)-\mathrm{Pt}-\mathrm{N}(41)$ & $87.0(3)$ \\
$\mathrm{N}(1)-\mathrm{Pt}-\mathrm{N}(41)$ & $89.1(3)$ & & $\mathrm{C}(2)-\mathrm{N}(1)-\mathrm{C}(10)$ & $119.7(7)$ \\
$\mathrm{N}(21)-\mathrm{Pt}-\mathrm{N}(31)$ & $92.0(3)$ & & $\mathrm{C}(11)-\mathrm{N}(12)-\mathrm{C}(13)$ & $116.3(9)$ \\
\hline
\end{tabular}




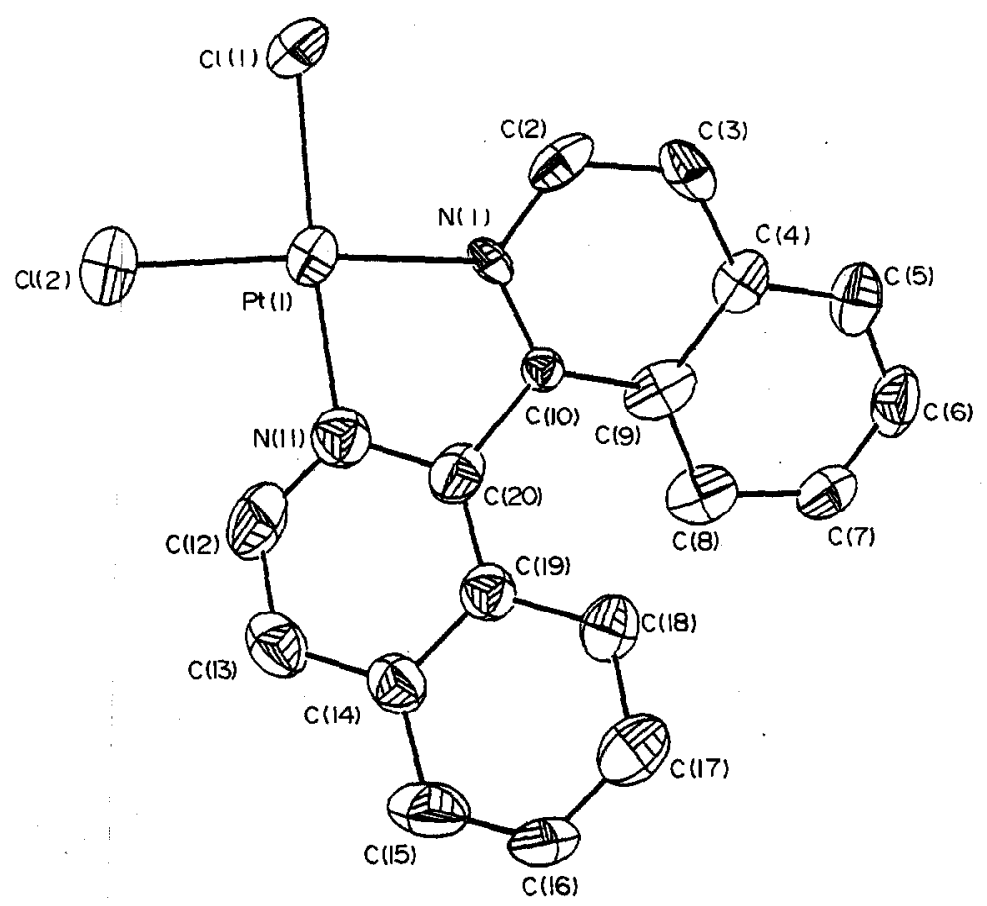

Fig. 1. Perspective drawing of $\left[\mathrm{Pt}(\mathrm{biq}) \mathrm{Cl}_{2}\right]$.

distances are $6.221,5.128$ and $6.414 \AA$ for $\mathbf{P t}(1)-P t(1), P t(2)-P t(2)$ and $P t(1)-P t(2)$, respectively, indicating no $\mathrm{Pt}-\mathrm{Pt}$ interaction. The reason why two forms exist in the crystal is not fully understood. From the unit cell diagam (Fig. 2) it can be seen that the twisted biq moiety in the type II complexes is interlocking with other biq units, hence, reasonably giving an enlarged dihedral angle.

A perspective drawing of the $\left[\mathrm{Pt}(\text { biq })(\text { dapy })_{3}\right]^{2+}$ cation is given in Fig. 3. The platinum atom is in a distorted square-planar configuration with $\mathrm{Pt}, \mathrm{N}(1)$,

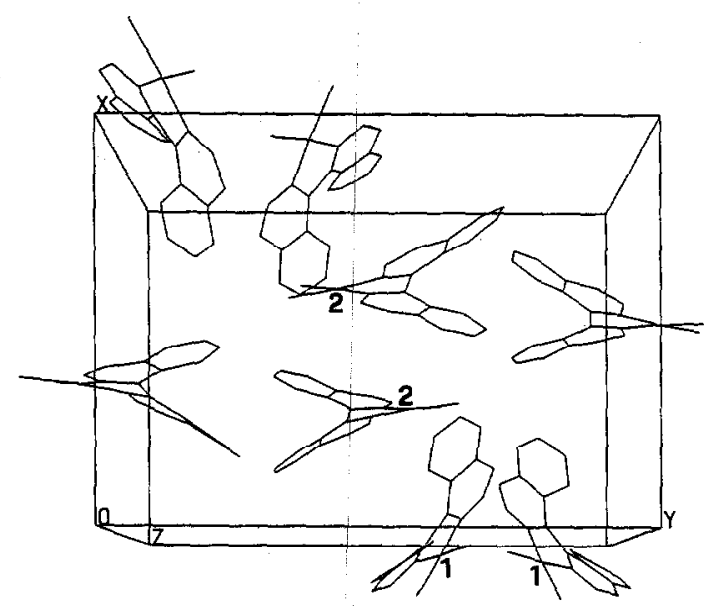

Fig. 2. The unit cell of $\left[\mathrm{Pt}(\mathrm{biq}) \mathrm{Cl}_{2}\right]$.
$N(21), N(31)$ and $N(41)$ all on the same plane. Three dapys are more or less perpendicular to the coordination plane. For the coordinated biq ligand the two isoquinoline moieties are almost planar, in which the deviation of atoms from the least-squares planes is within $0.072 \AA$. The biq ligand is in an $\eta^{1}$ coordination mode, despite it also being a bidentate chelating ligand. The dihedral angle between the two isoquinoline rings is $77.61^{\circ}$, which is substantially larger than the related values of $35.18^{\circ}$ and $41.12^{\circ}$ for the $\left[\mathrm{Pt}(\mathrm{biq}) \mathrm{Cl}_{2}\right]$ complex described above. The isoquinoline moiety with the non-coordinated nitrogen atom [N(12)] is weakly stacked adjacent to its neighbouring dapy ring. The interplane distance between the isoquinoline and dapy plane is $c a 3.5 \AA$. Such intramolecular $\pi-\pi$ stacking is absent in solution, as revealed by ${ }^{1} \mathrm{H}$ NMR study (vide infra). The angle $\mathrm{C}(2)-\mathrm{N}(1)-\mathrm{C}(10)$ $\left[119.7(7)^{\circ}\right][\mathrm{N}(1)$ is coordinated to platinum] is greater than the angle $\mathrm{C}(11)-\mathrm{N}(12)-\mathrm{C}(13)$ $\left[116.3(9)^{\circ}\right][\mathrm{N}(12)$ is uncoordinated]. The former value is similar to those in $\left[\mathrm{Pt}\right.$ (biq) $\left.\mathrm{Cl}_{2}\right]$, while the latter is typical of non-coordinated $s p^{2}$-hybridized nitrogen.

The ${ }^{1} \mathrm{H}$ NMR spectroscopic data are listed in Table 4. The ${ }^{1} \mathrm{H}$ NMR spectrum of $\left[\mathrm{Pt}(\mathrm{biq}) \mathrm{Cl}_{2}\right]$ in $\mathrm{CDCl}_{3}$, with the atomic numbering scheme, is shown in Fig. 4. Figure 5 shows the numbering schemes of $\left[\mathrm{Pt}(\text { biq)(dapy) })_{3}\right]^{2+}$ and $\left[\mathrm{Pt}(\text { biq })(\text { py })_{3}\right]^{2+}$. As discussed above, in the solid form the 


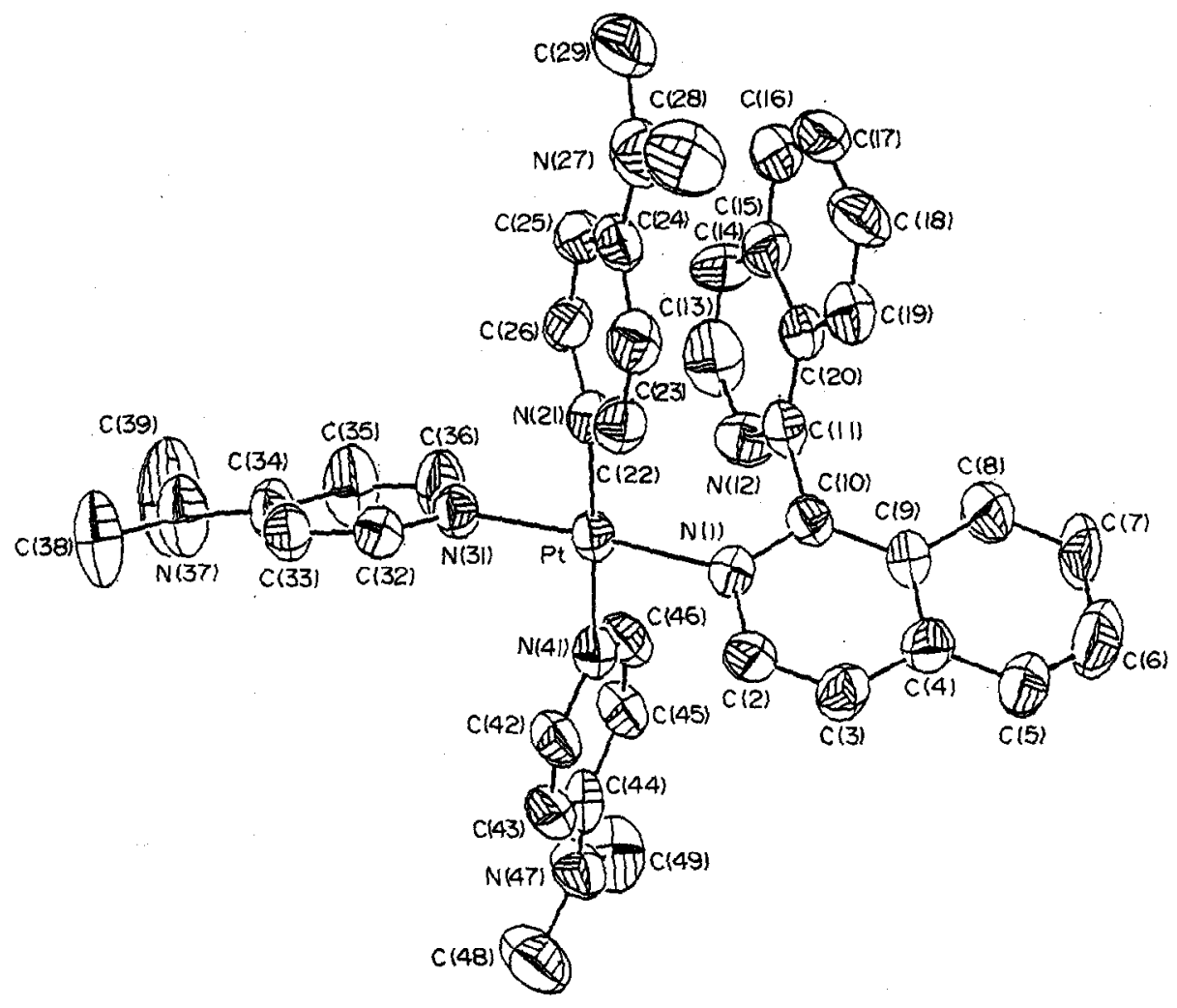

Fig. 3. Perspective drawing of $\left[\operatorname{Pt}(\text { biq })(\text { dapy })_{3}\right]^{2+}$.
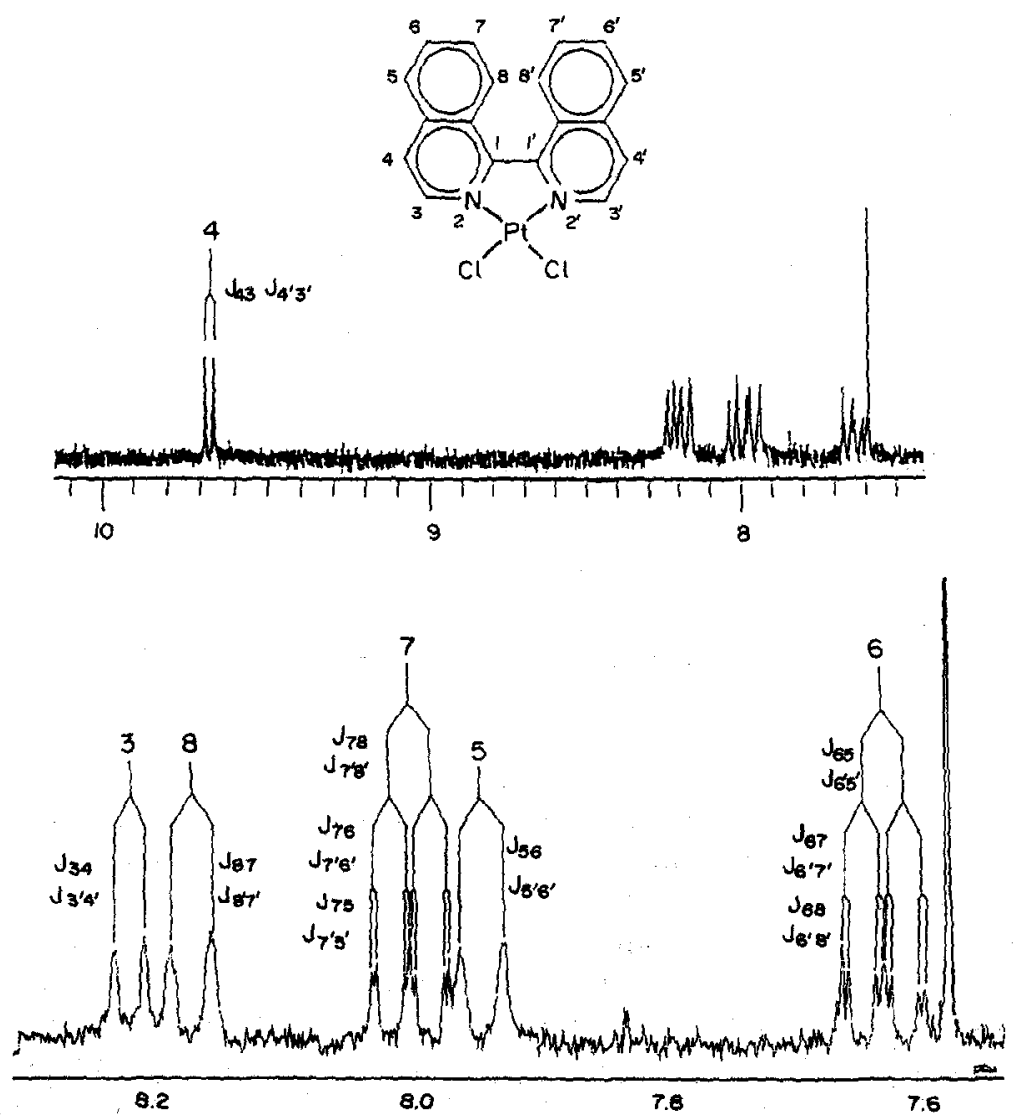

Fig. 4. 'H NMR spectrum and numbering scheme of $\left[\mathrm{Pt}(\mathrm{biq}) \mathrm{Cl}_{2}\right]$ in $\mathrm{CDCl}_{3}$, 
Table 4. Chemical shifts $(\delta, \mathrm{ppm})$ and coupling constants $(\mathrm{Hz})$ in 'H NMR spectra of platinum(II)-biq complexes; designation of protons is given in Figs 4 and 5

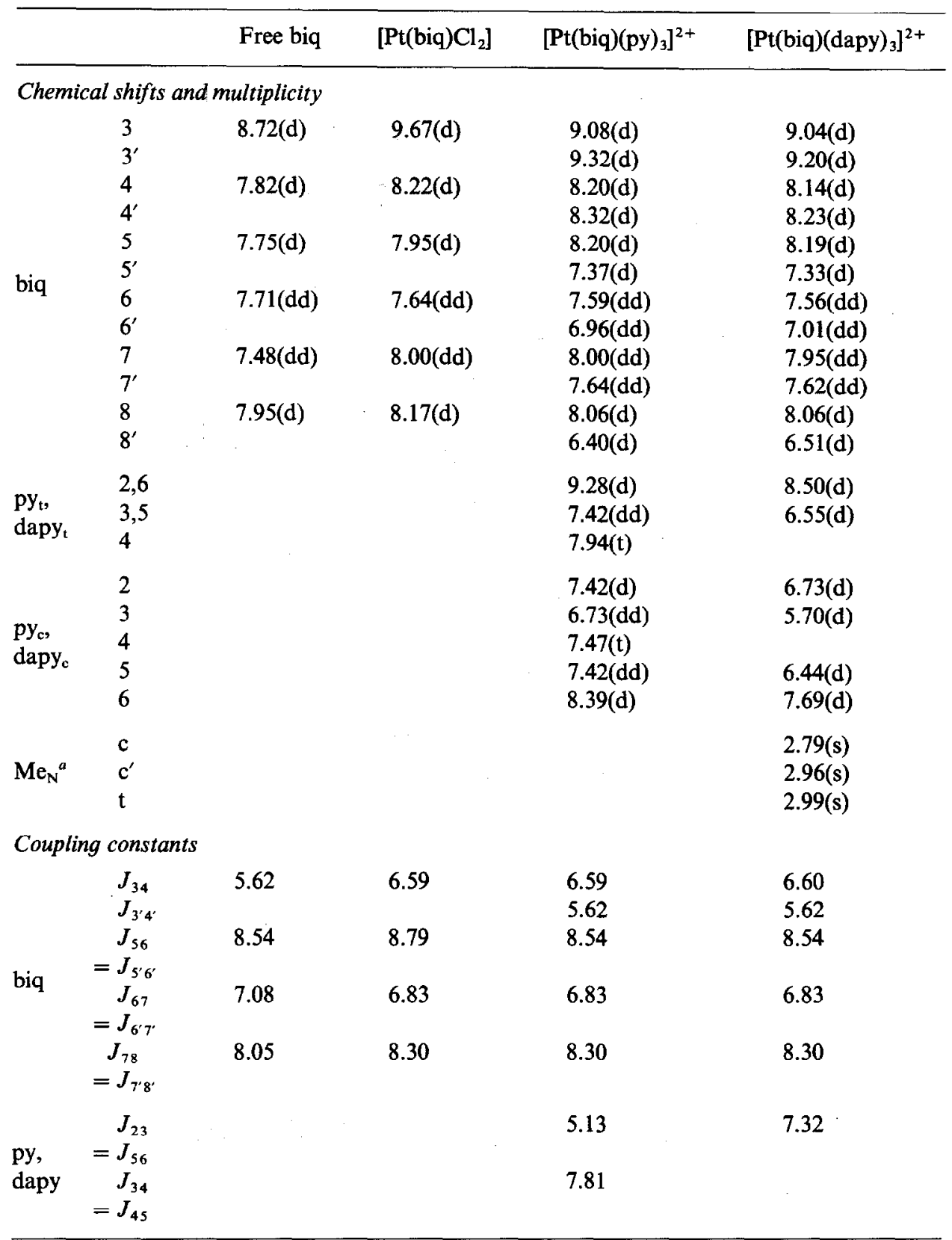

${ }^{a} \mathrm{Me}_{\mathrm{N}}=\mathrm{N}$-methyl protons.

$\mathrm{s}=$ singlet, $\mathrm{d}=$ doublet, $\mathrm{dd}=$ double doublet, $\mathrm{t}=$ triplet.

$\mathrm{Pt}-\mathrm{N}($ biq $)$ bond of $\left[\mathrm{Pt}(\right.$ biq $\left.)(\text { dapy })_{3}\right]\left(\mathrm{ClO}_{4}\right)_{2}$ is not free to rotate as it is restricted by two dapys cis to it and the $\pi-\pi$ stacking (vide supra). However, the ${ }^{1} \mathrm{H}$ NMR spectrum in acetonitrile solution reveals no $\pi-\pi$ stacking in solution. This is evidenced by the magnetic equivalence of two dapys cis to the biq ligand. The change in coordination mode of biq from $\eta^{2}$ to $\eta^{1}$ upon treatment of $\left[\mathrm{Pt}(\mathrm{biq}) \mathrm{Cl}_{2}\right]$ with nitrogen base is likely due to the ring strain of the five-membered ring in the $\eta^{2}-\mu_{1}$ coordination mode and the regain of the planarity of the isoquinoline rings in the $\eta^{1}-\mu_{1}$ geometry.

Similar to rhodium(I) and palladium(II), fourcoordinated platinum(II)-biq complexes are coordinatively unsaturated. The availability of vacant coordination sites and the $\mathrm{C}-\mathrm{H}$ bond activating property of platinum(II) should be useful in platinum(II)-biq complexes in asymmetric $\mathrm{C}-\mathrm{H}$ 

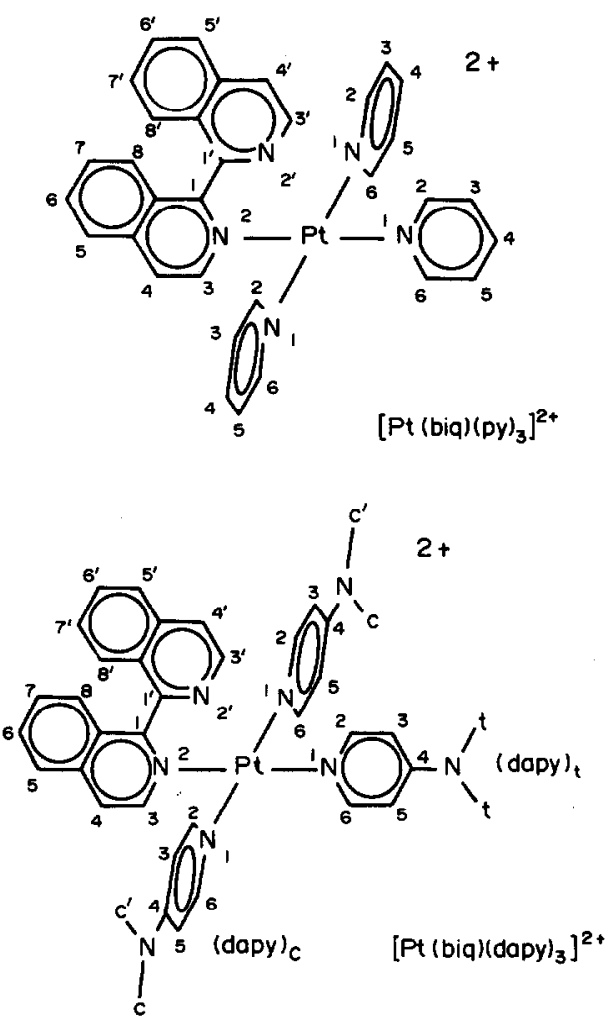

Fig. 5. Numbering schemes of $\left[\mathrm{Pt}(\text { biq })(\text { dapy })_{3}\right]^{2+}$ and $\left[\operatorname{Pt}(\text { biq })(\text { py })_{3}\right]^{2+}$.

bond oxidation. On the other hand, Calladine's rule is present in DNA. The base pairs have a propeller twist, $11^{\circ}$ for dG-DC and $17^{\circ}$ for dA-dT pairs. ${ }^{8}$
The small twist angles of $\left[\mathrm{Pt}(\mathrm{biq}) \mathrm{Cl}_{2}\right]$ compared with that of Toriumin's complex $\left[77.4(2)^{\circ}\right]^{9}$ may make chiral recognition binding to DNA possible.

Acknowledgements - We acknowledge support from the University of Hong Kong, the Hong Kong Research Grant Council and the National Science Council of Taiwan. CMC is grateful for the award of a visiting professorship, administered by the National Taiwain University.

\section{REFERENCES}

1. C. Rosini, L. Franzini, A. Raffaelli and P. Salvadori, Synthesis 1992, 503.

2. L. X. Dai, Z. H. Zhou, Y. Z. Zhang, C. I. Ni, Z. M. Zhang and Y. F. Zhou, J. Chem. Soc., Chem. Commun. 1987, 1760.

3. E. J. Gabe, Y. LePage, J.-P. Charland, F. L. Lee and P. S. White, J. Appl. Cryst. 1989, 22, 384.

4. M. Tiecco, L. Testaferri, M. Tingoli, D. Chianell and M. Montanucci, Synthesis 1984, 736.

5. E. Bielli, P. M. Gillard and B. T. Heaton, J. Chem. Soc., Dalton Trans. 1974, 2133.

6. P. M. Gidney, R. D. Gillard and B. T. Heaton, $J$. Chem. Soc., Dalton Trans. 1973, 132.

7. R. S. Osborn and D. Rogers, J. Chem. Soc., Dalton Trans. 1974, 9, 1002.

8. W. Saenger, Principles of Nucleic Acid Structure, Springer Advanced Texts in Chemistry (Edited by C. R. Cantor), p. 254. Springer-Verlag, New York (1984).

9. K. Toriumin, T. Ito and H. Takaya, Acta. Cryst., Sect. B 1982, 38, 807. 